\title{
Tverrfaglig samarbeid ga bedre
}

\section{legemiddelbehandling}

Sykepleiere som deltok i et læringsnettverk sammen med leger og farmasøyter fikk mer kunnskap om medisiner til eldre.

\section{Forfatter}

Ellen Mogård Larsen

FoU-leder

Utviklingssenter for sykehjem i Nordland

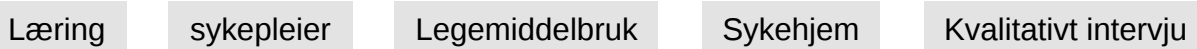

Sykepleien 2019 107(76986)(e-76986)

DOI: https://doi.org/10.4220/Sykepleiens.2019.76986

\section{Hovedbudskap}

Sykepleiere har fått ny, relevant kunnskap om legemiddelbehandling til eldre ved å delta i et tverrfaglig læringsnettverk om riktig legemiddelbruk i sykehjem. For å kunne implementere kunnskapen i praksis er man avhengig av et felles engasjement i praksisfellesskapet og ledere som etterspør kunnskap og gir rom for faglige refleksjoner.

Målet med læringsnettverket var å bidra til å redusere pasientskader og øke pasientsikkerheten gjennom konkret forbedringsarbeid i egen organisasjon. Kommunene har tatt i bruk den nye kunnskapen i varierende grad og på ulike måter. Det er gjennomført semistrukturelle intervjuer med sykepleiere i sju deltakerkommuner. 
Utviklingssenter for sykehjem i Nordland (USH)

arrangerte læringsnettverk for tverrfaglige

forbedringsteam med sykepleiere, leger og farmasøyter

i 2014 etter mal fra pasientsikkerhetsprogrammet

«Riktig legemiddelbruk i sykehjem» (1). Gjennom å

bidra med overordnet ramme med fastlagte

arbeidsformer, tidsfrister, rapporteringer og

deltakelse skulle USH være pådriver for teamenes

fremdrift og resultater (2).

Læringsnettverket gikk over ett år med tre samlinger.

Samlingene skulle gi kompetanse innen riktig legemiddelbruk og opplæring i forbedringsarbeid.

Erfaringsutveksling var sentralt på samlingene.

Mellom samlingene skulle deltakende team arbeide med forbedringstiltak på eget sykehjem. Vi anbefalte legemiddelgjennomganger (LMG) i tverrfaglige møter med sykepleier, farmasøyt og sykehjemslege med tema legemiddelvalg, doseringer og hensiktsmessig administrasjon av legemidler. Risiko og bivirkninger for pasienten sto sentralt, likeså interaksjoner mellom legemidler (1). De øvrige medarbeiderne på sykehjemmene skulle involveres i arbeidet.

USH erfarer at det har skjedd endringer og forbedringer i praksis gjennom deltakelse i dette læringsnettverket. Deltakerne har vist stort engasjement og interesse (2).

Forskning viser at det kan være vanskelig å få komplekse organisasjoner til å lære (3). Når to tilsynelatende like avdelinger gjennomfører samme fagutviklingstiltak, kan resultatene bli forskjellige. Noe av det samme viste sluttrapportene fra forbedringsteamene (2). Mens noen fikk gjennomført ønskede endringer, var det andre som ikke lyktes.

Dette er noe av bakgrunnen for min studie.

\section{Intervjuene}


Studien har en kvalitativ tilnærming. Jeg intervjuet sykepleiere fra sju sykehjem etter at de hadde deltatt i læringsnettverket. Informantene ble rekruttert gjennom virksomhetsledere.

Mine forskningsspørsmål omfattet sykepleiernes erfaringer med å delta i læringsnettverket, utvikle kvalitet på legemiddelbruk, samhandle med andre samt sykepleiernes vurderinger av nytteeffekt og overføringsverdi til andre. Det ble gjort lydopptak av intervjuene. Intervjuene ble transkribert.

\section{Fikk mer kunnskap}

Sykepleierne hadde fått ny kunnskap om legemiddelbruk til eldre og legemidlenes virkninger på pasienten. Flere av sykepleierne sa at de hadde lært mye på læringssamlingene og trakk også frem betydningen av erfaringsutveksling. Slik lærte man av andre og fikk innspill til nye løsninger. Sykepleierne oppdaget også betydningen av å dele egen kunnskap og erfaring med de andre i læringsnettverket. Erfaringsutvekslinger gjorde også at man kunne sammenlikne seg med de andre og få positiv bekreftelse på eget arbeid. Flere av sykepleierne mente at det de lærte på læringssamlingene, virket sterkt motiverende. De ble inspirerte og engasjerte. Sykepleier Gro sier:

«Mye av det vi lærer på kurs, kan være ganske ullent. Dette var veldig interessant, og det var veldig artig å jobbe med et slikt konkret tema. Jeg ble veldig inspirert og motivert for å få dette inn i praksis.»

Sykepleier Mette ble inspirert til å søke mer kunnskap. På samlingene fikk hun både ny kunnskap om legemidler til eldre og en konkret modell for forbedringsarbeid. Flere ga uttrykk for at dette var bra.

\section{Inspirerte hverandre}


På samlingene fikk forbedringsteamene mulighet til felles planlegging av forbedringsarbeidet. Enkelte sykepleiere erfarte at dette var inspirerende og engasjerende.

«Jeg synes det var veldig bra at vi fikk sitte i lag og planlegge og inspirere hverandre. Det synes jeg var mest matnyttig. Sykehjemslegen, fagansvarlig sykepleier, leder og jeg ble engasjert gjennom det vi lærte sammen. [...] Da var det greit at vi noterte under forelesningene og fikk tid til å planlegge etterpå. Vi fikk ideer om hva vi trengte å forbedre, og hva vi måtte skjerpe oss på.»

Sykepleieren opplevde det som motiverende å få ny kunnskap og så betydningen av at de ulike faggruppene lærte samtidig, og at de kunne starte planlegging av eget forbedringsarbeid med det samme. «Fersk og ny» kunnskap ble umiddelbart satt inn i en prosess med avklaring av roller og ansvar og fordeling av arbeidsoppgaver. Sykepleierne jeg intervjuet, opplevde det å omsette kunnskap til praktisk arbeid som positivt og spennende.

Ikke alle kommuner har farmasøyt, men sykepleierne viste kreative måter å engasjere farmasøyt på. I en kommune sendte de legemiddellister til en farmasøyt i nærliggende by, for så å reise dit for et møte. Andre hadde farmasøyten til stede på sykehjemmet hele dager og foretok mange LMG-er. Der farmasøyten var mer tilgjengelig, deltok hun ved de ukentlige legemiddelgjennomgangene. Sykepleierne jeg intervjuet, hadde stort faglig utbytte av dette tverrfaglige samarbeidet. Sykepleier Olga sier det slik: 
«Jeg erfarer at de ulike medlemmene av

forbedringsteamet har ulike erfaringer, noe som styrker

forbedringsarbeidet. Kvaliteten på

legemiddelbehandlingen er blitt bedre. Aldri har

fokuset på medikamenthåndtering og

medikamentbehandling vært større. Vi reflekterer mer

over egen praksis og hvilket utbytte pasienten har av

behandlingen. Jeg kjenner at jeg blir veldig stolt over

hva vi får til, og det er veldig godt å høre at andre har

nytte av den erfaringen vi har gjort oss.»

\section{Lærte opp kollegaer}

Den kunnskapen som forbedringsteamene fikk, skulle bringes videre i egen organisasjon - i første omgang gjennom målrettede forbedringstiltak. Sykepleier Anne sier følgende:

«Det har vært litt vanskelig å forklare hva dette har gått ut på og å få med de andre i avdelingen. De har nok følt seg litt utenfor i starten av læringsnettverket, selv om vi har prøvd å inkludere og fortelle hva vi holdt på med. Men når de først har vært med på det, så har de skjønt hvorfor vi var så superengasjerte og ville ha dette i gang. Det var veldig godt å få denne tilbakemeldingen fra andre sykepleiere.»

Sykepleiere forteller at hjelpepleiere som delte ut medisiner fra dosett, fikk større kunnskaper om hvorfor pasientene fikk sine medisiner, og hvordan disse virket. Hjelpepleiere ble tryggere og fikk også en mer aktiv rolle i observasjoner av pasientenes legemiddelbruk.

$\AA$ involvere kollegaer i forbedringsarbeidet var en forutsetning for positive endringer i praksis, ifølge sykepleierne. Å sette ny kunnskap i system krevde et målrettet arbeid. Felles fokus, god planlegging og avsatt tid var suksessfaktorer for å lykkes, ifølge sykepleierne jeg intervjuet. Sykepleier Marit sier: 
«Personlig har jeg hatt veldig stort utbytte av læringsnettverket, og jeg ser at det har forplantet seg videre i avdelingen. Som nyutdannet sykepleier erfarer jeg at kunnskapen jeg allerede har, blir brukt i større grad etter læringsnettverket. Vi benytter kunnskapen mer når vi går gjennom medisiner og ser på hvilke utfordringer pasienter har.»

\section{Lederens betydning}

For å sikre forankring, støtte og spredning i organisasjonen forventet USH at ledere skulle delta i læringsnettverket. Sykepleier Randi hadde denne erfaringen:

«Vi kan takke for godt resultat gjennom et godt lederskap. Vår leder har mange års erfaring som sykepleier og er veldig fokusert på at det skal være rett, det vi gjør. Det smitter igjen nedover i avdelingen.»

Sykepleier Turid hadde andre erfaringer. Lederen påla henne en stor arbeidsbyrde hun ble alene om:

«Det eneste jeg savner, var at vi kunne vært flere i forbedringsteamet. Nå ble gruppa for liten. Jeg sa det til sjefen min da jeg kom hjem, at vi ble så få. [...] Jeg visste ikke på forhånd hva dette gikk ut på. Det er ganske mye arbeid mellom samlingene, både tenkning og planlegging. Det var også vanskelig å forklare mine kollegaer.»

Sykepleierne jeg intervjuet, var ansatt i små kommuner. Flere var alene om det sykepleiefaglige ansvaret på vakt, hadde mange pasienter og stor vaktbelastning. De opplevde likevel å ha liten innflytelse og mulighet for kontinuitet og faglige prioriteringer. Sykepleier Monica sier: 
«Jeg har stor betydning som sykepleier og har mye fagansvar og lærer mye i jobben. Imidlertid har jeg stor arbeidsbelastning og møter liten forståelse hos administrasjon og politikere.»

Enkelte sykepleiere hadde erfaringer med å overføre kunnskapen til hjemmetjenesten. De øvrige var usikre på om eldre utenfor sykehjemmet fikk nyte godt av det de hadde lært om legemiddelgjennomganger.

\section{Krav til forbedring}

Sykehjemmene er en viktig del av kommunenes helseog omsorgstjeneste og har store faglige krav til kvalitet i tjenesten. Det er lovpålagt med systematisk arbeid med kvalitetsforbedring og pasient- og brukersikkerhet i helse- og omsorgstjenesten (4). Målsettingen er at kvalitetsarbeid skal være integrert i ordinær virksomhet. Studien viser at man får et godt resultat der leder engasjerer seg og støtter opp.

\section{三 «Studien viser at man får et godt resultat der lederen engasjerer seg og støtter opp.»}

Andre studier viser at når ansatte tilegner seg

kompetanse, erfarer de påfallende ofte at den ikke tillegges vekt av lederen, og at kompetanse ikke blir tatt i bruk på en systematisk måte (4).

I dette læringsnettverket var det USH som stilte krav til forbedringsteamene. Teamene sendte inn statusrapporter og månedlige målinger. Sykepleierne ga tilbakemelding om at dette var motiverende da de så fremgangen bedre. En viktig forutsetning for endring av praksis handler om motivasjon (4). Ønsket om å søke å gjøre ting stadig bedre er en grunnleggende forutsetning for kvalitet. Viktige motivasjonsfaktorer for læring var ifølge sykepleierne ros og anerkjenning. Ledere og medarbeidere må derfor etterspørre faglig kunnskap i større grad, og sykepleiere må få rom til å foreta faglige refleksjoner. 
En av de største utfordringene er å utnytte den kunnskapen organisasjonen allerede har. Denne kunnskapen får først verdi når den brukes i daglig praksis og kommer pasientene til gode.

\section{Utvikling på jobb}

Sykepleierne i studien opplevde å lykkes med forbedringsarbeidet når alle medarbeidere var inkluderte. Blåka og Filstad (5) peker på praksisfellesskapets betydning for læring og kunnskapsutvikling. De understreker at læring er relasjonell og har forankring i en følelse av tilhørighet og felles mål.

Kunnskapsutviklingen som foregår på arbeidsplassen, vil være forankret i situasjonen og blant kollegaene som jobber sammen. Kunnskapen utvikler seg i denne relasjonen, gjennom observasjonene, gjennom å praktisere og ha mulighet til å observere den kunnskapen de representerer. Det betyr at denne kunnskapen ikke kan overføres til en ny situasjon og gi de samme resultatene.

For å nyttiggjøre kunnskapen må man utvikle en kultur basert på tillit, hvor medarbeiderne ser det helt naturlig å involvere hverandre og løse arbeidsoppgaver (5).

Dette er en farbar vei for å implementere ny kunnskap i praksis. Ledere bør i større grad se denne muligheten. Ved å etterspørre hva sykepleiere kan og har lært og skatte entusiasmen og motivasjonen, blir det enklere å få til endringer i praksis.

\section{Samarbeid med farmasøyt}

Sykepleiere og sykehjemsleger har alltid hatt et etablert samarbeid rundt pasientens legemiddelbehandling. Det som var nytt, var at farmasøyten var med i det tverrfaglige samarbeidet. De som fikk avtaler med en farmasøyt om tverrfaglige samarbeid om legemiddelbehandling, lyktes bedre i forbedringsarbeidet. De ulike faggruppene er likeverdige parter med ulike innfallsvinkler til temaet. 


\section{Ikke kultur for å dele}

Studien avdekket også at det ikke er kultur for å dele kunnskap og videreføre erfaringer mellom tjenestesteder i egen kommune (2). Statlige føringer presenterer de overordnede rammene for arbeidet med kvalitet og pasientsikkerhet i årene fremover (6) og peker på at utfordringer er felles for hele helse- og omsorgstjenesten. I tillegg er det spesielle utfordringer knyttet til samhandlingen mellom tjenestene.

Det kreves mye kompetanse i helse- og omsorgstjenestene, men det mangler en infrastruktur som gjør det mulig å sette kompetanse i sentrum.

\section{三 «De utfordringene velferdssamfunnet står overfor, kan vi ikke spare oss ut av. De må vi utvikle oss ut av.»}

Den nasjonale politiske vektleggingen på kompetanse bør følges opp av samme kvalitetsorienterte holdningen ute i tjenestene (4). Kommunene bør ha mer oppmerksomhet på hvordan praksisfellesskapet kan være med på å utvikle organisasjonen videre, synliggjøre en eksisterende kunnskapsutvikling og dra nytte av gjensidig læring i praksisfellesskapet. De utfordringene velferdssamfunnet står overfor, kan vi ikke spare oss ut av. De må vi utvikle oss ut av (7).

Ansatte må i større grad betraktes som medspillere og viktige ressurser i denne utviklingen. Medarbeidere og ledere i helse- og omsorgstjenestene vil ha stort utbytte av å etterspørre hva sykepleiere kan og har lært, og sykepleiere bør i større grad ta ansvar gjennom å stå frem med sin kompetanse og kvalitet.

En svakhet med studien er at det er få sykepleiere i utvalget, og at man har innhentet erfaringer fra bare ett læringsnettverk.

\section{Konklusjon}


Sykepleiere har fått økt kunnskapen sin gjennom å delta i læringsnettverket og er med på å øke kvaliteten på legemiddelbehandlingen for pasienter i sykehjem. Rammene for at denne kunnskapen blir nyttiggjort i praksis, kan bedres.

Politiske føringer krever at vi tenker nytt innen organisering og drift av helsetjenestene for å nå målsettinger med tilgjengelige faglige ressurser. De samlede kompetanseutfordringene må ses i en sammenheng. Jeg anbefaler ledere å fokusere mer på hvordan praksisfellesskapet kan være med på å utvikle organisasjonene videre gjennom å være klar over og ta i bruk kompetansen som medarbeidere opparbeider seg. Videre at de får tid og rom for forbedringsarbeid slik at det kommer pasientene til gode på best mulig måte.

Utviklingssentrene har en pådriverrolle for fag- og kvalitetsutvikling. Studien bekrefter at læringsnettverk er egnet til fagutvikling, implementering av kunnskapsbasert praksis og samhandling med andre faggrupper.

\section{Referanser}

1. Helsedirektoratet. Pasientsikkerhetsprogrammet «I trygge hender 24/7». Riktig legemiddelbruk i sykehjem. Oslo: Helsedirektoratet. Tilgjengelig fra: https://www.pasientsikkerhetsprogrammet.no/omoss/innsatsomr\%C3\%A5der/riktig-legemiddelbruk-isykehjem (nedlastet 22.05.2019).

2. Utviklingssenter for sykehjem i Nordland. Riktig legemiddelbruk i sykehjem i Nordland sør - fra pilot til læringsnettverk. Lofoten: Utviklingssenter for sykehjem i Nordland; 2015. Rapport 1/2015. 
3. Larsen TA, Knutsen B. Læring i handling.

Sluttrapport fra et faglig utviklingsprosjekt fra fem

sykehjem i Nord-Norge (LIA-prosjektet). Tilgjengelig

fra: https://docplayer.me/45636002-Laering-i-

handling-sluttrapport-fra-et-faglig-utviklingsprosjektved-fem-sykehjem-i-nord-norge-toril-agnete-larsenliv-berit-knudsen.html (nedlastet 23.04.2019).

4. Haukelien H, Vike H, Bakken R. Kompetanse og faglig infrastruktur i helse- og omsorgstjenestene: evaluering av prosjektet EVUK. Bø:

Telemarksforsking; 2009. Tilgjengelig fra:

https://brage.bibsys.no/xmlui/handle/11250/2439293 (nedlastet 23.04.2019).

5. Blåka G, Filstad C. Læring i helseorganisasjoner. Oslo: Cappelen Damm; 2007.

6. Meld. St. nr. 10 (2012-2013). God kvalitet trygge tjenester - kvalitet og pasientsikkerhet i helseog omsorgstjenester. Oslo: Helse og omsorgsdepartementet; 2012.

7. Meld. St. nr. 29 (2012-2013). Morgendagens omsorg. Oslo: Helse- og omsorgsdepartementet; 2012. 